\title{
Faktor-Faktor yang Mempengaruhi Persentase Penduduk Miskin di Indonesia Tahun 2015-2018 Menggunakan Regresi Data Panel
}

\author{
Ian Tryaldi Halim ${ }^{1}$, Annisa Putri Ramadhanty ${ }^{2}$, Dewi Retno Oscarini ${ }^{3}$, \\ Galang Madya Putra ${ }^{4}$, Helen Fricylya Br Tobing ${ }^{5}$, Rani Nooraeni ${ }^{6}$ \\ 1,2,3,4,5,6 Program Studi Diploma IV Statistika, Jurusan Statistika dan Kependudukan, \\ Politeknik Statistika STIS, \\ Jakarta, Indonesia 11480 \\ 211709743@stis.ac.id; 2211709565@stis.ac.id; 211709621@stis.ac.id; \\ 211709710@stis.ac.id; 211709734@stis.ac.id; raninoor@stis.ac.id
}

\begin{abstract}
Indonesia as a country rich in natural resources has not been able to make it as a country that is free from poverty. The percentage of poor people in Indonesia is still high, is still less efficient, the government's policy in alleviating poverty. This can be seen from the increase in the human development index, gross domestic product and the number of health facilities that are not counted by reducing the percentage of the poor population. The purpose of this study is to describe the percentage of poor people in Indonesia and to analyze the factors that influence the percentage of poor people in Indonesia. This study uses panel data regression analysis using the Random Effect Model (REM) method. The results showed the regional gross domestic product and the level of openness significantly open to the percentage of Indonesia's poor population. While the human development index and the amount of health development are not significant to the percentage of poor people in Indonesia. From the results of this study, Indonesia can optimize employment opportunities that can be released so that it can improve the state of the country. This implementation is expected to increase the number of poor people in Indonesia which can be significant.
\end{abstract}

Keywords: Panel Regression; Random Effect Model; Poverty

Abstrak - Indonesia sebagai negara yang kaya dengan sumber daya alam belum mampu menjadikannya sebagai negara yang terlepas dari masalah kemiskinan. Persentase penduduk miskin di Indonesia yang masih tinggi mengindikasikan masih kurang efisiennya kebijakan pemerintah dalam mengentaskan kemiskinan. Hal ini terlihat dari peningkatan indeks pembangunan manusia, produk domestic bruto dan jumlah sarana kesehatan yang tidak diikuti dengan penurunan persentase penduduk miskin. Tujuan penelitian ini adalah untuk menggambarkan persentase penduduk miskin di Indonesia dan untuk menganalisis faktor-faktor yang mempengaruhi persentase penduduk miskin di Indonesia. Penelitian ini menggunakan analisis regresi data panel menggunakan metode Random Effect Model (REM). Hasil penelitian menujukkan bahwa produk domestic regional bruto dan tingkat pengangguran terbuka berpengaruh signifikan terhadap persentase penduduk miskin Indonesia. Sementara indeks pembangunan manusia dan jumlah sarana kesehatan tidak berpengaruh signifikan terhadap persentase penduduk miskin di Indonesia. Dari hasil penelitian ini Indonesia dapat mengoptimalkan pembukaan lapangan pekerjaan sehingga dapat menyerap pengangguran sehingga dapat memperbaiki kondisi perekonomian negara .Dengan terlaksananya hal tersebut diharapkan persentase penduduk miskin di Indonesia dapat turun secara signifikan.

Kata kunci: Regresi Data Panel, Random Effect Model, Kemiskinan

\section{PENDAHULUAN}

Salah satu tujuan dari pembangunan nasional adalah meningkatkan kinerja perekonomian agar mampu menciptakan lapangan kerja dan menata kehidupan yang layak bagi seluruh rakyat Indonesia. Hal ini selaras dengan salah satu tujuan yang dicanangkan oleh pemerintah dalam agenda tujuan pembangunan berkelanjutan (Sustainable Development Goals) yaitu mengakhiri segala bentuk kemiskinan dimanapun selama 15 tahun kedepan hingga tahun 2030. Target ini mensyaratkan bahwa setiap warga negara indonesia memiliki akses terhadap pelayanan dasar dan memiliki hak untuk menikmati suatu standar kehidupan yang layak serta pemerintah harus dapat menjamin masyarakat yang sangat miskin dengan suatu program jaminan sosial.

Kemiskinan didefinisikan sebagai ketidakmampuan individu dalam memenuhi kebutuhan dasar minimal untuk hidup layak baik makanan maupun nonmakanan (BPS), yang ditandai dengan rendahnya tingkat pendapatan yang 
akan berdampak pada berkurangnya kemampuan individu untuk memenuhi standar hidup rata rata seperti standar kesehatan maupun standar pendidikan.

Menurut Nurkse penyebab kemiskinan bermuara pada teori lingkaran kemiskinan (vicious circle of poverty). Nurkse mengatakan bahwa adanya keterbelakangan dan ketertinggalan SDM, ketidaksempurnaan pasar, serta kurangnya modal menyebabkan rendahnya produktivitas. Rendahnya produktivitas mengakibatkan rendahnya pendapatan yang diterima yang akan berdampak pada rendahnya tabungan dan investasi yang mengakibatkan rendahnya akumulasi modal sehingga penciptaan lapangan pekerjaan menjadi rendah. Hal ini terus berulang sehingga terbentuk lingkaran kemiskinan.

Masalah kemiskinan merupakan masalah klasik yang hampir terjadi pada semua negara. Masalah kemiskinan di Indonesia sendiri terbilang cukup rumit karena luas wilayah, beragamnya kondisi sosial budaya masyarakat. Selain itu, masalah kemiskinan juga bersifat multidimensional karena bukan hanya menyangkut ukuran pendapatan, tetapi juga kerentanan dan kerawanan untuk menjadi miskin, kegagalan dalam pemenuhan hak dasar, dan adanya perbedaan perlakuan seseorang atau kelompok masyarakat dalam menjalani kehidupan secara bermartabat.

Indonesia merupakan negara yang kaya akan sumber daya alam, akan tetapi hal tersebut tidak menjadikan Indonesia terlepas dari masalah kemiskinan, hal ini terlihat dari masih banyak masyarakat Indonesia yang masih tergolong ke dalam kategori miskin.

Tabel 1. Persentase Penduduk Miskin di Indonesia Tahun 2015-2018

\begin{tabular}{ccccc}
\hline Tahun & 2015 & 2016 & 2017 & 2018 \\
\hline $\begin{array}{c}\text { Persentase } \\
\text { Penduduk } \\
\text { Miskin }\end{array}$ & 11.175 & 10.78 & 10.9775 & 10.87875 \\
\hline
\end{tabular}

Dapat dilihat dari tabel 1, bahwa persentase penduduk miskin di Indonesia masih cukup tinggi. Jumlah penduduk miskin tertinggi dari tahun 2015-2018 terjadi pada tahun 2015 dengan persentase sebesar 11.175 persen. Kemudian menurun pada tahun 2016, dan kembali naik pada tahun 2017. Apabila dilihat secara keseluruhan, persentase jumlah penduduk miskin di Indonesia cenderung berfluktuatif Karena terus mengalami kenaikan dan penurunan setiap tahunnya meskipun tidak terlalu signifikan. Padahal berbagai upaya telah dilakukan oleh pemerintah dalam menanggulangi masalah kemiskinan, bahkan pemerintah menjadikan pengentasan kemiskinan sebagai salah satu program yang di prioritaskan. Salah satu upaya penanggulangan kemiskinan yang telah dibuat oleh pemerintah adalah membuat program penanggulangan kemiskinan. Akan tetapi upaya yang telah dilakukan oleh pemerintah dalam menangani masalah kemiskinan belum efektif karena penurunan persentase jumlah penduduk miskin dari tahun 2015-2018 belum signifikan.

Berdasarkan uraian yang telah dijelaskan, maka pada penelitian ini akan dilakukan analisa mengenai faktorfaktor yang berpengaruh terhadap persentase penduduk miskin di Indonesia melalui pemodelan regresi data panel.
Regresi data panel digunakan untuk melihat bagaimana perkembangan pengaruh setiap factor yang diduga mempengaruhi persentase penduduk miskin di Indonesia dari tahun 2015 hingga 2018.

Menurut BPS (2016) kemiskinan adalah ketidakmampuan dari sisi ekonomi, materi dan fisik untuk mencukupi kebutuhan dasar makanan dan bukan makanan yang di ukur dengan pengeluaran. Dalam teori Nurkse (dalam Kuncoro 1997:107) kemiskinan bertumpu pada teori lingkaran setan kemiskinan, adanya ketidaksempurnaan pasar, kurangnya modal, dan keterbelakangan Sumber daya manusia menyebabkan produktivitas rendah.

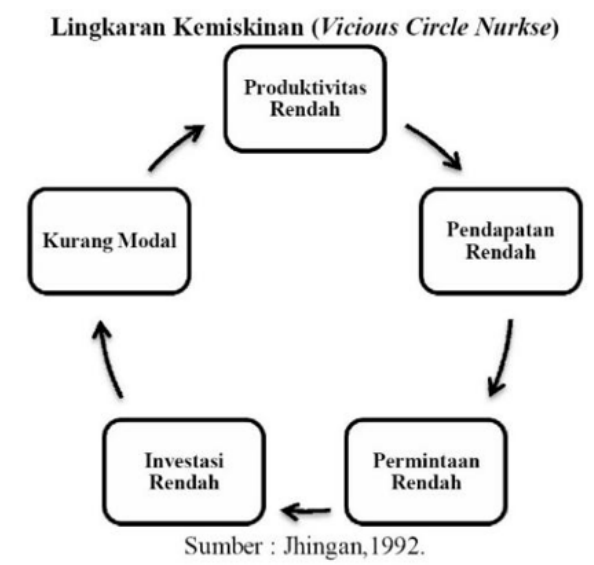

Gambar 1. Lingkaran Kemiskinan

Ada beberapa faktor yang menjadi penyebab kemiskinan di suatu daerah diantaranya adalah tingkat pengangguran terbuka (TPT), pertumbuhan ekonomi, sarana kesehatan, dan Indeks Pembangunan Manusia (IPM).

Menurut BPS Indonesia tingkat pengangguran terbuka (TPT) adalah persentase jumlah pengangguran terhadap jumlah angkatan kerja. Tingkat pengangguran di ukur dari banyaknya jumlah orang yang menganggur. Semakin banyak jumlah pengangguran maka akan mengakibatkan permasalahan sosial, diantaranya semakin banyak pengangguran maka semakin minim pendapatan masyarakat tersebut yang dapat memicu terjadinya kemiskinan.

Pertumbuhan ekonomi dapat dilihat dari nilai Produk Domestik Bruto (PDB) dan untuk wilayah/ regional dalam suatu periode tertentu dapat dilihat dari data Produk Domestik Regional Bruto (PDRB), baik atas dasar harga berlaku maupun atas dasar harga konstan. PDRB menggambarkan kemampuan suatu daerah mengelola sumber daya alam yang dimilikinya (Firmansyah, 2016;2).

Arsyad (2016) menjelaskan intervensi untuk memperbaiki kesehatan dari pemerintah juga merupakan suatu alat kebijakan penting untuk mengurangi kemiskinan. Salah satu faktor yang mendasari kebijakan ini adalah perbaikan kesehatan akan meningkatkan produktivitas golongan miskin: kesehatan yang lebih baik akan meningkatkan daya kerja, mengurangi hari tidak bekerja dan menaikkan output energi. Oleh karena, itu kesehatan yang baik akan berpengaruh negatif terhadap tingkat kemiskinan. Kesehatan yang baik dapat dicapai jika sarana kesehatan tersedia di sekitar tempat kita tinggal. 
Indeks Pembangunan Manusia (IPM) merupakan indeks komposit yang digunakan untuk mengukur pencapaian rata-rata suatu negara dalam tiga hal mendasar pembangunan manusia, yaitu: lama hidup, pendidikan dan standar hidup. Terdapat hubungan penting antara IPM dan kapasitas pendapatan produktif. Orang miskin menggunakan tenaga mereka untuk berpartisipasi dalam pertumbuhan ekonomi, tetapi kemiskinan akibat kurangnya pendidikan, serta gizi dan kesehatan yang buruk - mengurangi kapasitas mereka untuk bekerja. Dengan demikian, akibat rendahnya IPM adalah orang miskin tidak dapat mengambil keuntungan oportunitas pendapatan produktif karena terjadinya pertumbuhan ekonomi (Ravi Kanbur dan Lyn Squire, 1999).

Meinny Kolibu, Vekie A. Rumate, dan Daisy S.M. Engka melakukan penelitian yang berjudul Pengaruh Tingkat Inflasi, Investasi, Pertumbuhan Ekonomi dan Tingkat Pengangguran Terhadap Tingkat Kemiskinan di Provinsi Sulawesi Utara. Dari penelitian tersebut diperoleh informasi mengenai bahwa terdapat 3 faktor yang mempengaruhi kemiskinan di Provinsi Sulawesi Utara yaitu investasi, pertumbuhan ekonomi dan tingkat pengangguran.

Ari Kristin Prasetyoningrum dan U. Sulia Sukmawati melakukan penelitian yang berjudul Analisis Pengaruh Indeks Pembangunan Manusia (IPM), Pertumbuhan Ekonomi dan Pengagguran Terhadap Kemiskinan di Indonesia. Dari penelitian tersebut diperoleh informasi mengenai bahwa terdapat 2 faktor yang mempengaruhi kemiskinan di Indonesia yaitu IPM dan tingkat pengangguran.

Noor Zuhdiyaty dan David Kaluge melakukan penelitian yang berjudul Analisis Faktor-Faktor yang Mempengaruhi Kemiskinan di Indonesia Selama Lima Tahun Terakhir (Studi Kasus Pada 33 Provinsi). Dari penelitian tersebut diperoleh informasi mengenai bahwa terdapat faktor yang mempengaruhi kemiskinan di Indonesia yaitu Indeks Pembangunan Manusia (IPM).

Dicky Wahyudi dan Tri Wahyu Rejekingsih melakukan penelitian yang berjudul Analisis Kemiskinan di Jawa Tengah. Dari penelitian tersebut diperoleh informasi mengenai bahwa terdapat faktor yang mempengaruhi kemiskinan di Provinsi Jawa Tengah yaitu kesehatan, pendidikan, pengeluaran pemerintah, dan pengangguran.

\section{METODOLOGI PENELITIAN}

\subsection{Metode Pengumpulan Data}

Penelitian ini menggunakan data sekunder yang berasal dari Badan Pusat Statistik (BPS) dalam salah satu publikasi nya yang berjudul Statistik Indonesia 2019 yang mencakup keempat variabel bebas yaitu Indeks Pembangunan Manusia (X1) tahun 2015-2018, Produk Domestik Regional Bruto (X2) tahun 2015-2018, Jumlah sarana kesehatan (X3) tahun 2015-2018 dan Tingkat Pengangguran Terbuka (X4) tahun 2015-2018. Serta variabel terikat yaitu Persentase Penduduk Miskin tahun 2015-2018.

\subsection{Metode Analisis}

Model persamaan data panel yang merupakan gabungan dari data cross section dan data time series adalah sebagai berikut :

$$
\begin{gathered}
Y_{i t}=\alpha+\beta_{1} X_{1 i t}+\beta_{2} X_{2 i t}+\cdots \\
+\beta_{n} X_{n i t}+e_{i t}
\end{gathered}
$$

Dimana :

$$
\begin{array}{ll}
\mathrm{Y}_{i t} & =\text { variabel terikat }(\text { dependent }) \\
\mathrm{X}_{l i t} & =\text { variabel bebas }(\text { independent }) \\
\mathrm{i} & =\text { entitas ke- } \mathrm{i} \\
\mathrm{t} & =\text { periode ke- } \mathrm{t}
\end{array}
$$

Estimasi model regresi linear berganda dari beberapa variabel bertujuan untuk memprediksi parameter model regresi yaitu nilai konstanta $(\alpha)$ atau biasa disebut intersep dan koefisien regresi $\left(\beta_{\mathrm{i}}\right)$ atau biasa disebut slope. Model regresi data panel yang akan diestimasi membutukan asumsi terhadap intersep, slope dan variabel gangguannya. Asumsi-asumsi tersebut yaitu :

1. Diasumsikan intersep dan slope adalah tetap sepanjang periode waktu dan seluruh entitas/ perusahaan. Perbedan intersep dan slope dijelaskan oleh variabel gangguan (residual)

2. Diasumsikan slope adalah tetap tetapi intersep berbeda entitas

3. Diasumsikan slope tetap tetapi intersep berbeda baik antar waktu maupun antar individu

4. Diasumsikan intersep dan slope berbeda antar individu

5. Diasumsikan intersep dan slope berbeda antar waktu dan antar individu

Dari berbagai kemungkinan yang disebutkan diatas, munculah berbagai kemungkinan model/teknik yang dapat dilakukan oleh regresi data panel. Dalam banyak literatur hanya asumsi pertama sampai ketiga saja yang sering menjadi acuan dalam pembentukan model regresi data panel. Menurut Widarjono (2007,251), untuk mengestimasi parameter model dengan data panel terdapat tiga model yang sering ditawarkan, yaitu :

\section{Model Common Effect}

Teknik ini paling sederhana untuk mengestimasi parameter model data panel, yaitu dengan mengkombinasi data cross section dan time series sebagai satu kesatuan tanpa melihat adanya perbedaan waktu dan entitas (individu).

\section{Model Efek Tetap ( Fixed Effect)}

Pendekatanmodelfixedeffectmengasumsikan bahwa intersep dari setiap individu adalah berbeda sedangkan slope antar individe adalah tetap (sama). Teknik ini menggunakan variabel dummy untuk menangkap adanya perbedaan intersep antar individu.

\section{Model Efek Random ( Random Effect )}

Pendekatan yang dipakai dalam Random Effect mengasumsikan setiap kelompok mempunyai 
peredaan intersep, yang mana intersep tersebut adalah variabel random atau stokastik. Model ini sangat berguna jika individu (entitas) yang diambil sebagai sampel adalah dipilih secara random dan merupakan wakil populasi. Teknik ini juga memperhitungkan bahwa error mungkin berkorelasi sepanjang cross section dan time series.

\subsection{Pemilihan Model (Teknik Estimasi) Regresi Data Panel}

Pada dasarnya ketiga model estimasi data panel dapat dipilih sesuai dengan keadaan penelitian, dilihat dari jumlah sampel dan variabel penelitiannya. Namun demikian, ada beberapa cara yang dapat digunakan untuk menentukan teknik mana yang paling tepat dalam mengestimasi parameter data panel. Menurut Widarjono (2007: 258), ada tiga uji untuk memilih teknik estimasi data panel. Pertama, uji statistik F digunakan untuk memilih antara metode Commom Effect atau metode Fixed Effect. Kedua, uji Hausman yang digunakan untuk memilih antara metode Fixed Effect atau metode Random Effect. Ketiga, uji Lagrange Multiplier (LM) digunakan untuk memilih antara metode Commom Effect atau metode Random Effect.

\subsection{Uji Statistik F (Uji Chow)}

Untuk mengetahui model mana yang lebih baik dalam pengujian data panel, bisa dilakukan dengan penambahan variabel dummy sehingga dapat diketahui bahwa intersepnya berbeda dapat diuji dengan uji Statistik F. Uji ini digunakan untuk mengetahui apakah teknik regresi data panel dengan metode Fixed Effect lebih baik dari regresi model data panel tanpa variabel dummy atau metode Common Effect.

Hipotesis pada uji chow adalah :

\section{$\mathrm{H}_{0}$ : Common Effect Model \\ $\mathrm{H}_{1}$ : Fixed Effect Model}

Dasar penolakan terhadap hipotesis diatas adalah dengan membandingkan perhitungan F-statistik dengan F-tabel. Perbandingan dipakai apabila hasil $\mathrm{F}$ hitung lebih besar $(>)$ dari $\mathrm{F}$ tabel maka $\mathrm{H}_{0}$ ditolak yang berarti model yang paling tepat digunakan adalah Fixed Effect Model. Begitupun sebaliknya, jika $\mathrm{F}$ hitung lebih kecil $(<)$ dari $\mathrm{F}$ tabel maka $\mathrm{H}_{0}$ diterima dan model yang digunakan adalah Common Effect Model.

Perhitungan F statistik didapat dari Uji Chow dengan rumus :

$$
F=\frac{\frac{\left(S S E_{1}-S S E_{2}\right)}{(n-1)}}{\frac{S S E_{2}}{(n t-n-k)}}
$$

Dimana:

$\mathrm{SSE}_{1}$ : Sum Square Error dari model Common Effect $\mathrm{SSE}_{2}$ : Sum Square Error dari model Fixed Effect

n : Jumlah cross section

nt : Jumlah cross section $\mathrm{x}$ jumlah time series

$\mathrm{k} \quad$ : Jumlah variabel independen
Apabila nilai $\mathrm{F}$ hitung $>\mathrm{F}$ tabel $=\{\alpha: \mathrm{df}(\mathrm{n}-1$, nt$\mathrm{n}-\mathrm{k}\}$, maka hipotesis nul ditolak yang artinya model yang tepat untuk regresi data panel adalah model Fixed Effect. Dan sebaliknya, apabila nilai $\mathrm{F}$ hitung lebih kecil dari $\mathrm{F}$ kritis maka hipotesis nul diterima yang artinya model yang tepat untuk regresi data panel adalah model Common Effect.

\subsection{Uji Hausman}

Setelah selesai melakukan uji Chow dan didapatkan model yang tepat adalah Fixed Effct, maka selanjutnya kita akan menguji model manakah antara model Fixed Effect atau Random Effect yang paling tepat, pengujian ini disebut sebagai uji Hausman.

Uji Hausman dapat didefinisikan sebagai pengujian statistik untuk memilih apakah model Fixed Effect atau Random Effect yang paling tepat digunakan. berikut:

Pengujian uji Hausman dilakukan dengan hipotesis

\section{$\mathrm{H}_{0}:$ Random Effect Model \\ $\mathrm{H}_{1}$ : Fixed Effect Model}

Uji Hausman akan mengikuti distribusi chi-squares sebagai berikut:

$$
\begin{aligned}
& W=\hat{q}^{\prime} \operatorname{Var}\left(\hat{q}^{\prime}\right)^{-1} \hat{q} \\
& W=\left(\hat{\beta}_{M E T}-\hat{\beta}_{M E A}\right)^{\prime}\left[\operatorname { v a r } \left(\hat{\beta}_{M E T}-\right.\right. \\
& \left.\left.\hat{\beta}_{M E A}\right)\right]^{-1}\left(\hat{\beta}_{M E T}-\hat{\beta}_{M E A}\right)
\end{aligned}
$$

dimana :

$$
\begin{aligned}
& \hat{\beta}_{M E T}=\text { vektor estimasi slope model efek tetap } \\
& \hat{\beta}_{M E A}=\text { vektor estimasi slope model efek random }
\end{aligned}
$$

Jika nilai $\mathrm{W}>\chi_{(\alpha, K)}^{2}$ atau nilai $\mathrm{p}$-value kurang dari $\alpha$, maka hipotesis $\mathrm{H} 0$ akan ditolak sehingga model yang terpilih adalah model tetap.

\subsection{Uji Lagrange Multiplier}

Lagrange Multiplier (LM) adalah uji untuk mengetahui apakah model Random Effect atau model Common Effect (OLS) yang paling tepat digunakan. Uji signifikasi Random Effect ini dikembangkan oleh Breusch Pagan. Metode Breusch Pagan untuk uji signifikasi Random Effect didasarkan pada nilai residual dari metode OLS. Adapun nilai statistik LM dihitung berdasarkan formula sebagai berikut:

$$
L M=\frac{n T}{2(T-1)}\left[\frac{\sum_{i=1}^{n}\left(T \overline{\hat{e}}_{i}\right)^{2}}{\sum_{i=1}^{n} \sum_{t=1}^{T} \hat{e}_{i t}^{2}}-1\right]^{2}
$$

Dimana :

$\mathrm{n}=$ jumlah individu

$\mathrm{T}=$ jumlah periode waktu

$\mathrm{e}=$ residual metode Common Effect (OLS)

Hipotesis yang digunakan adalah :

$\mathrm{H}_{0}$ : Common Effect Model

$\mathrm{H}_{1}$ : Random Effect Model 
Uji LM ini didasarkan pada distribusi chi-squares dengan degree of freedom sebesar jumlah variabel independen. Jika nilai LM $>\chi_{(a, \mathrm{~K})}^{2}$, maka kita menolak hipotesis nul, yang artinya estimasi yang tepat untuk model regresi data panel adalah metode Random Effect dari pada metode Common Effect. Sebaliknya jika nilai LM $<\chi_{(\alpha, \mathrm{K})}^{2}$, maka kita menerima hipotesis nul, yang artinya estimasi yang digunakan dalam regresi data panel adalah metode Common Effect bukan metode Random Effect.

\subsection{Pengujian Asumsi Klasik (Multikolinieritas dan Heteroskedastisitas)}

Regresi data panel memberikan alternatif model, Common Effect, Fixed Effect dan Random Effect. Model Common Effect dan Fixed Effect menggunakan pendekatan Ordinary Least Squared (OLS) dalam teknik estimasinya, sedangkan Random Effect menggunakan Generalized Least Squares (GLS) sebagai teknik estimasinya. Uji asumsi klasik yang digunakan dalam regresi linier dengan pendekatan Ordinary Least Squared (OLS) meliputi uji Linieritas, Autokorelasi, Heteroskedastisitas, Multikolinieritas dan Normalitas.

Model Random Effect menggunakan metode estimasi GLS sehingga hanya memerlukan asumsi normalitas dan nonmultikoinearitas karena metode estimasi tersebut telah menanggulangi asumsi lain seperti heteroskedastisitas dan autokorelasi.

\subsection{Uji Normalitas}

Uji normalitas dilakukan untuk memastikan bahwa data yang dikumpulkan mengikuti distribusi normal atau diambil dari populasi yang berdistribusi normal.

Ada beberapa cara untuk menguji normalitas data, baik itu dengan visual maupun dengan analisis statistik seperti shapiro-wilk dan kolmogorov-smirnov. Analisis visual dapat dilakukan dengan menampilkan histogram, boxplot, dan Q-Q plot. Sementara analisis statistik dapat dilakukan dengan Kolmogorov-Smirnov dan Shapiro-Wilk.

\subsection{Uji Multikolinieritas}

Regresi data panel tidak sama dengan model regresi linier, oleh karena itu pada model data panel perlu memenuhi syarat terbebas dari pelanggaran asumsi-asumsi dasar (asumsi klasik). Meskipun demikian, adanya korelasi yang kuat antara variabel bebas dalam pembentukan sebuah model (persamaan) sangatlah tidak dianjurkan terjadi, karena hal itu akan berdampak kepada keakuratan pendugaan parameter, dalam hal ini koefisien regresi, dalam memperkirakan nilai yang sebenarnya. Korelasi yang kuat antara variabel bebas dinamakan multikolinieritas.

Cara mengetahui ada atau tidak nya multikolinieritas, yaitu dapat dilihat dari :

1. Melihat kekuatan korelasi antar variabel bebas. Jika ada korelasi antar variabel bebas $>0,8$ dapat diindikasikan adanya multikolinearitas.

2. Melihat nilai standar error koefisien regresi parsial. Jika ada nilai standar error $>1$, maka dapat diindikasikan adanya multikolinearitas.

3. Melihat rentang confidence interval. Jika rentang confidence interval sangat lebar, maka dapat diindikasikan adanya multikolinearitas.

4. Melihat nilai Condition Index dan eigenvalue. Jika nilai condition index $>30$ dan nilai eigenvalue $<0,001$ dapat diindikasikan adanya multikolinearitas.

5. Melihat nilai Tolerance dan Variance Inflating Factor (VIF). Jika nilai Tolerance $<0,1$ dan VIF $>10$ dapat diindikasikan adanya multikolinearitas. Sebagian pakar menggunakan batasan Tolerance $<0,2$ dan VIF $>5$ dalam menentukan adanya multikolinearitas. Para pakar juga lebih banyak menggunakan nilai Tolerance dan VIF dalam menentukan adanya Multikolinearitas di dalam model regresi linear berganda dibandingkan menggunakan parameter-parameter yang lainnya. Hal ini juga dalam prakteknya menggunakan SPSS, kita sudah disuguhkan dengan hasil yang instant, dimana kita bisa langsung lihat nilai keduanya di dalam output SPSS.

\subsection{Uji Heteroskedastisitas}

Uji heteroskedastisitas digunakan untuk melihat apakah residual dari model yang terbentuk memiliki varians yang konstan atau tidak. Suatu model yang baik adalah model yang memiliki varians dari setiap gangguan atau residualnya konstan. Heteroskedastisitas adalah keadaan dimana asumsi tersebut tidak tercapai, dengan kata lain dimana adalah ekspektasi dari eror dan adalah varians dari eror yang berbeda tiap periode waktu.

Dampak adanya heteroskedastisitas adalah tidak efisiennya proses estimasi, sementara hasil estimasinya tetap konsisten dan tidak bias. Eksistensi dari masalah heteroskedastisitas akan menyebabkan hasil Uji-t dan Uji-F menjadi tidak berguna (miss leanding).

Ada beberapa metode yang dapat digunakan untuk mendeteksi heteroskedastisitas dengan menggunakan analisis statistik yaitu uji glejser, uji park dan uji spearman, sedangkan dengan analisis visual menggunakan grafik dengan melihat ada atau tidaknya pola tertentu pada grafik scatterplot antara SRESID dan ZPRED adalah sumbu Y dimana sumbu Y yang telah diprediksi dan Sumbu X adalah Residual (Y Prediksi - Y Sesungguhnya).

\subsection{Uji Autokorelasi}

Uji Autokorelasi adalah sebuah analisis statistik yang dilakukan untuk mengetahui adakah korelasi variabel yang ada di dalam model prediksi dengan perubahan waktu. Oleh karena itu, apabila asumsi autokorelasi terjadi pada sebuah model prediksi, maka nilai residual tidak lagi berpasangan secara bebas, melainkan berpasangan secara autokorelasi.

Pengujian autokorelasi dapat dilakukan dengan analisis statistik menggunakan uji Durbin Watson, Uji Breucsh Godfrey, Uji Durbin Watson, dan The Engle's ARCH Test.

Pada penelitian ini, peneliti memilih menggunakan metode durbin watson untuk mendeteksi autokorelasi. 
Uji Durbin watson akan menghasilkan nilai Durbin Watson (DW) yang nantinya akan dibandingkan dengan dua nilai Durbin Watson Tabel, yaitu Durbin Upper (DU) dan Durbin Lower DL). Dikatakan tidak terdapat autokorelasi jika nilai DW $>$ DU dan (4-DW) $>$ DU atau bisa dinotasikan juga sebagai berikut: (4-DW) $>$ DU $<$ DW.

\subsection{Pemilihan Model (Teknik Estimasi) Regresi Data Panel \\ Pada dasarnya ketiga model estimasi data panel} dapat dipilih sesuai dengan keadaan penelitian, dilihat dari jumlah sampel dan variabel penelitiannya. Namun demikian, ada beberapa cara yang dapat digunakan untuk menentukan teknik mana yang paling tepat dalam mengestimasi parameter data panel. Menurut Widarjono (2007: 258), ada tiga uji untuk memilih teknik estimasi data panel. Pertama, uji statistik F digunakan untuk memilih antara metode Commom Effect atau metode Fixed Effect. Kedua, uji Hausman yang digunakan untuk memilih antara metode Fixed Effect atau metode Random Effect. Ketiga, uji Lagrange Multiplier (LM) digunakan untuk memilih antara metode Commom Effect atau metode Random Effect. Untuk lebih jelasnya dapat dilihat pada gambar 1 .

\section{HASIL DAN PEMBAHASAN}

Dari tabel 2, terlihat bahwa indeks pembangunan manusia, produk domestic regional bruto, dan jumlah sarana kesehatan terus mengalami kenaikan tiap tahunnya serta tingkat pengangguran terbuka yang terus mengalami penurunan. Sedangkan persentase penduduk miskin terbilang cukup berfluktuatif. Seharusnya peningkatan jumlah sarana kesehatan, produk domestic regional bruto, dan indeks pembangunan manusia serta penurunan tingkat pengangguran terbuka ini diikuti dengan penurunan persentase penduduk miskin. Akan tetapi hal yang terjadi tidak demikian.

Tabel 2. Tabel Persentase Penduduk Miskin, IPM, PDRB, Jumlah Sarana Kesehatan, TPT di Indonesia Tahun 2015, 2016, 2017, dan 2018

\begin{tabular}{cccccc}
\hline Tahun & $\begin{array}{c}\text { Persentase } \\
\text { Penduduk } \\
\text { Miskin }\end{array}$ & IPM & PDRB & $\begin{array}{c}\text { Jumlah } \\
\text { Sarana } \\
\text { Kesehatan }\end{array}$ & TPT \\
\hline 2015 & 11.175 & 69.55 & 48706.29706 & 1949 & 5.995 \\
\hline 2016 & 10.78 & 70.18 & 51657.51324 & 2046 & 5.555 \\
\hline 2017 & 10.9775 & 70.81 & 55680.01176 & 2198 & 5.415 \\
\hline 2018 & 10.87875 & 71.39 & 59802.205 & 2269 & 5.235 \\
\hline
\end{tabular}

3.2 Faktor-Faktor yang Mempengaruhi Persentase Penduduk Miskin di Indonesia Tahun 2015-2018

\subsubsection{Pemilihan Data Panel}

\section{- Uji Chow}

Uji chow merupakan pengujian yang digunakan untuk melihat apakah model FEM lebih baik dibandingkan dengan model CEM terlihat dari tabel. 3 .
Tabel 3. Hasil Regresi Data Panel

\begin{tabular}{cccc}
\hline \multirow{2}{*}{ Variabel } & \multicolumn{3}{c}{ Koefisien Model } \\
\cline { 2 - 4 } C & CEM & FEM & REM \\
\hline $\begin{array}{c}\text { LN Indeks Pembangunan } \\
\text { Manusia (X1) }\end{array}$ & 0.038003 & 0.020998 & 0.003397 \\
\hline LN PDRB (X2) & -5.18477 & -2.256968 & -3.004233 \\
\hline $\begin{array}{c}\text { LN Jumlah Sarana Kesehatan } \\
\text { (X3) }\end{array}$ & -0.215586 & -0.225888 & -0.149654 \\
\hline $\begin{array}{c}\text { LN Tingkat Penggangguran } \\
\text { Terbuka (X4) }\end{array}$ & 0.085933 & 0.139092 & 0.119520 \\
\hline F.Statistic & 30.18658 & 807.1001 & 36.21761 \\
\hline R2 & 0.463746 & 0.995494 & 0.525139 \\
\hline Prob. F Stat & 0.000000 & 0.000000 & 0.000000 \\
\hline
\end{tabular}

Dari tabel 4, terlihat bahwa nilai probabilitas yang didapatkan adalah sebesar 0.000 dimana nilai tersebut lebih kecil dibandingkan dengan $\alpha=0.05$ yang menandakan bahwa pengujian memberikan hasil tolak $H_{0}$ sehingga dapat disimpulkan dengan taraf signifikansi 5\% terdapat cukup bukti untuk menyatakan bahwa model FEM lebih baik dibandingkan dengan model CEM.

\begin{tabular}{cccc}
\multicolumn{4}{c}{ Tabel 4. Uji Chow } \\
\hline Effect Test & Statistic & d.f & Prob \\
\hline Cross Section F & 469.469848 & 33.98 & 0.0000 \\
\hline Cross Section Chi Square & 689.445183 & 33 & 0.0000 \\
\hline
\end{tabular}

\section{- Uji Hausman}

Uji Hausman merupakan pengujian yang digunakan untuk melihat apakah model REM lebih baik dibandingkan dengan model FEM. Hasil pengolahan chow adalah sebagai berikut:

Tabel 5. Uji Hausman

\begin{tabular}{cccc}
\hline Effect Test & Statistic & d.f & Prob \\
\hline Cross Section Random & 6.455125 & 4 & 0.1676 \\
\hline
\end{tabular}

Dari tabel 5, terlihat bahwa nilai probabilitas yang didapatkan adalah sebesar 0.1676 dimana nilai tersebut lebih besar dibandingkan dengan $\alpha=0.05$ yang menandakan bahwa pengujian memberikan hasil gagal tolak $H_{0}$ sehingga dapat disimpulkan dengan taraf signifikansi 5\% terdapat cukup bukti untuk menyatakan bahwa model REM lebih baik dibandingkan dengan model FEM.

Dari hasil pengujian diatas dapat disimpulkan bahwa dari ketiga model yang ada, model Random Effect Model (REM) merupakan model terbaik

\subsubsection{Pemeriksaan Asumsi Klasik}

Model Random Effect menggunakan metode estimasi GLS sehingga hanya memerlukan asumsi normalitas dan non-multikolinearitas karena metode tersebut telah menanggulangi asumsi lain seperti heteroskedastisitas dan autokorelasi. Pengujian normalitas secara empiris dilakukan menggunakan uji Jarque Berra. Hasil dari uji normalitas adalah sebagai berikut: 
Tabel 6. Uji Normalitas

\begin{tabular}{cc}
\hline Jarque Berra & 5.713487 \\
\hline Probability & 0.057456 \\
\hline
\end{tabular}

Dari pengujian Jarque Berra yang terlihat pada tabel 6, didapatkan nilai probabilitas sebesar 0.057456 dimana nilai tersebut lebih besar dibandingkan $\alpha=0.05$ yang menandakan bahwa pengujian memberikan hasil gagal tolak H0 sehingga dapat disimpulkan dengan taraf signifikansi $5 \%$ cukup bukti untuk mengatakan bahwa model terpilih telah berdistribusi normal. Asumsi selanjutnya adalah asumsi non multikolinearitas, untuk memeriksa asumsi ini dilakukan dengan pemeriksaan korelasi antar variabel bebas. Hasil dari pemeriksaan korelasi antar variabel bebas adalah sebagai berikut:

Tabel 7. Uji Multikolinearitas

\begin{tabular}{ccccc}
\hline & $\mathrm{X} 1$ & $\mathrm{X} 2$ & $\mathrm{X} 3$ & $\mathrm{X} 4$ \\
\hline $\mathrm{X} 1$ & 1.000000 & 0.167026 & 0.284455 & 0.229881 \\
\hline $\mathrm{X} 2$ & 0.167026 & 1.000000 & 0.454994 & 0.352735 \\
\hline $\mathrm{X} 3$ & 0.284455 & 0.454994 & 1.000000 & 0.074001 \\
\hline $\mathrm{X} 4$ & 0.229881 & 0.352735 & 0.074001 & 1.000000 \\
\hline
\end{tabular}

Asumsi non-multikolinearitas dikatakan terlanggar apabila korelasi antar variabel bebas lebih dari 0.8 .Dari pengujian Multikolinearitas yang terlihat pada tabel 7 ,terlihat bahwa korelasi antar variabel bebas tidak terlalu kuat sehingga asumsi multikolinearitas tidak terlanggar.

\subsubsection{Pengujian Keberartian Model}

Dapat dilihat model terpilih yang terlihat pada tabel 8 , didapatkan besaran koefisien determinasi yang disesuaikan (Adj $\mathrm{R}^{2}$ ) sebesar 0.510664. nilai tersebut terbilang cukup dan menunjukkan bahwa 51.06 persen keragaman yang ada pada variabel terikat telah mampu dijelaskan oleh variabel bebas, sedangkan sisanya dijelaskan oleh variabel lain yang tidak tercakup dalam penelitian ini. Secara simultan, model terpilih menunjukkan nilai $p$-value uji $\mathrm{F}$ adalah sebesar 0.0000 atau lebih kecil dibandingkan dengan nilai $\alpha(0.05)$. Berdasarkan nilai tersebut kesimpulan yang dapat diambil adalah tolak $H_{0}$ yang berarti pada taraf signifikansi 5\% terdapat cukup bukti untuk menyatakan bahwa terdapat minimal satu variabel independent yang memiliki pengaruh secara signifikan terhadap variabel dependen. Selanjutnya adalah melakukan uji parsial dengan melihat nilai p-value masing masing variabel, didapatkan bahwa pada taraf signifikansi 5\% terdapat cukup bukti untuk menyatakan bahwa variabel PDRB, dan tingkat pengangguran terbuka memiliki pengaruh secara signifikan terhadap persentase penduduk miskin di Indonesia tahun 2015 hingga 2018, sedangkan variabel indeks pembangunan manusia dan jumlah sarana kesehatan tidak memiliki pengaruh signifikan terhadap persentase penduduk miskin Indonesia tahun 2015 hingga 2018.
Tabel 8. Ringkasan Hasil Estimasi Model REM

\begin{tabular}{cccc}
\hline Variabel & Intersep & Uji Statistic & Prob \\
\hline $\mathbf{( 1 )}$ & $\mathbf{( 2 )}$ & $\mathbf{( 3 )}$ & $\mathbf{( 4 )}$ \\
\hline $\mathrm{C}$ & 16.17854 & 6.291114 & 0.0000 \\
\hline $\begin{array}{c}\text { LN Indeks } \\
\text { Pembangunan } \\
\text { Manusia (X1) }\end{array}$ & 0.003397 & 0.097005 & 0.9299 \\
\hline $\begin{array}{c}\text { LN PDRB (X2) } \\
\text { LN Jumlah Sarana } \\
\text { Kesehatan (X3) }\end{array}$ & -0.149654 & -1.630478 & 0.1054 \\
\hline $\begin{array}{c}\text { LN Tingkat } \\
\text { Penggangguran } \\
\text { Terbuka (X4) }\end{array}$ & 0.119520 & 2.310133 & 0.0224 \\
\hline & Ringkasan Statistic \\
\hline F.Statistic & 36.21761 & R2 & 0.525139 \\
\hline $\begin{array}{c}\text { Prob. F Stat } \\
\text { Adjusted }\end{array}$ & 0.510664 \\
\hline
\end{tabular}

\subsubsection{Interpretasi Model}

Persamaan regresi data panel dengan model random effect adalah sebagai berikut.

$$
\begin{aligned}
& L N Y_{i t}=16.17854+ \\
& 0.003397 L N X 1_{i t}- \\
& 3.004233 L N X 2_{i t}- \\
& 0.149654 L N X 3_{i t}+0.119520 L N X 2_{i t}
\end{aligned}
$$

Berdasarkan tabel 8, variabel IPM memiliki p-value 0.9299 yang dimana nilai tersebut lebih tinggi dibandingkan $\alpha=0.05$. Artinya dengan tingkat signifikansi 5\% tidak terdapat cukup bukti bahwa IPM berpengaruh signifikan terhadap persentase penduduk miskin di Indonesia. Hal ini terlihat juga pada tabel 1 , pada tabel tersebut terlihat bahwa kenaikan IPM di Indonesia dari tahun 2015 hingga 2018 tidak diikuti dengan penurunan persentase penduduk miskin di Indonesia dari tahun 2015 hingga 2018

Berdasarkan tabel 8 variabel PDRB memiliki $p$-value 0.0002 yang dimana nilai tersebut lebih rendah dibandingkan $\alpha=0.05$. Artinya dengan tingkat signifikansi $5 \%$ terdapat cukup bukti bahwa PDRB berpengaruh signifikan terhadap persentase penduduk miskin di Indonesia. Setiap PDRB meningkat 1 persen maka akan menurunkan persentase penduduk miskin sebesar 3.004233 persen dengan asumsi ceteris paribus. Hal ini dikarenakan PDRB merupakan nilai tambah tambah barang dan jasa yang dihasilkan keseluruhan kegiatan ekonomi diseluruh wilayah pada periode tertentu, sehingga PDRB yang besar menggambarkan bahwa wilayah tersebut memiliki perekonomian yang bagus. Daerah yang memiliki perekonomian yang bagus, biasanya cenderung memiliki jumlah penduduk miskin yang sedikit. Hal ini sejalan dengan penelitian Nur Fajriah (2016) yang menjelaskan bahwa PDRB perkapita berpengaruh secara positif dan signifika terhadap persentase penduduk miskin.

Berdasarkan tabel 8, variabel jumlah sarana kesehatan memiliki p-value 0.1054 yang dimana nilai tersebut lebih tinggi dibandingkan $\alpha=0.05$. Artinya dengan tingkat signifikansi 5\% tidak terdapat cukup bukti bahwa jumlah sarana kesehatan berpengaruh signifikan 
terhadap persentase penduduk miskin di Indonesia. Hal ini terlihat juga pada tabel 1, pada tabel tersebut terlihat bahwa kenaikan jumlah sarana kesehatan di Indonesia dari tahun 2015 hingga 2018 tidak diikuti dengan penurunan persentase penduduk miskin di Indonesia dari tahun 2015 hingga 2018

Berdasarkan tabel 8 variabel TPT memiliki $p$-value 0.0224 yang dimana nilai tersebut lebih rendah dibandingkan $\alpha=0.05$. Artinya dengan tingkat signifikansi 5\% terdapat cukup bukti bahwa TPT berpengaruh signifikan terhadap persentase penduduk miskin di Indonesia. Setiap TPT meningkat 1 persen maka akan meningkatkan persentase penduduk miskin sebesar 0.119520 persen dengan asumsi ceteris paribus . Hal ini dikarenakan wilayah yang memiliki tingkat pengangguran yang tinggi berarti dependensi rasio wilayah tersebut juga tinggi sehingga satu orang penduduk menanggung banyak orang. Daerah yang memiliki tingkat pengangguran tinggi, biasanya memiliki jumlah penduduk miskin yang banyak.

\section{KESIMPULAN}

1. Secara umum, persentase penduduk miskin di Indonesia pada tahun 2015-2018 cenderung fluktuatif yaitu mengalami penurunan dan kenaikan secara berturut-turut. Pada tahun 2015 persentase penduduk miskin mencapai angka tertinggi, sedangkan pada tahun 2016 persentase penduduk miskin mengalami penurunan yang signifikan, kemudian pada tahun 2017 mengalami kenaikan, dan pada tahun 2018 mengalami penurunan kembali. Hal ini sesuai dengan tabel Persentase Penduduk Miskin, IPM, PDRB, Jumlah Sarana Kesehatan dan TPT di Indonesia Tahun 2015-2018.

2. Berdasarkan hasil analisis yang dilakukan, dapat disimpulkan bahwa variabel IPM tidak berpengaruh secara signifikan terhadap persentase penduduk miskin. Hal ini dikarenakan komponen yang dominan di IPM yaitu hanya pendapatan perkapita, tidak termasuk angka harapan hidup dan rata-rata lama sekolah, sehingga hanya berpengaruh pada kemajuan status ekonomi suatu negara.

3. Untuk variabel PDRB setelah dilakukan analisis, dapat disimpulkan bahwa PDRB berpengaruh secara positif dan signifikan terhadap persentase penduduk miskin di Indonesia. Hal ini dikarenakan PDRB merupakan nilai tambah tambah barang dan jasa yang dihasilkan keseluruhan kegiatan ekonomi diseluruh wilayah pada periode tertentu, sehingga PDRB yang besar menggambarkan bahwa wilayah tersebut memiliki perekonomian yang bagus. Daerah yang memiliki perekonomian yang bagus, biasanya cenderung memiliki jumlah penduduk miskin yang sedikit.

4. Berdasarkan hasil analisis yang dilakukan, dapat disimpulkan bahwa variabel jumlah sarana kesehatan tidak berpengaruh secara signifikan terhadap persentase penduduk miskin. Dalam kasus ini, pemerintah telah melakukan berbagai upaya untuk meningkatkan derajat kesehatan masyarakat, mulai dari memberikan penyuluhan akan pentingnya pola hidup sehat, menyediakan sarana dan prasarana kesehatan sampai ke daerah-daerah terpencil, menambah jumlah tenaga kesehatan, mengusahakan obat murah (generik) hingga asuransi kesehatan dan pengobatan gratis bagi masyarakat miskin, hal ini ditunjukkan pada peningkatan jumlah sarana kesehatan yang naik dari tahun ke tahun. Sehingga tidak sesuai dengan data fluktuatif naik turunnya persentase penduduk, yang seharusnya berbanding terbalik dengan peningkatan sarana kesehatan.

5. Sementara untuk variabel TPT setelah dilakukan analisis disimpulkan bahwa variabel TPT berpengaruh secara signifikan terhadap persentase penduduk miskin di Indonesia. Hal ini dikarenakan wilayah yang memiliki tingkat pengangguran yang tinggi berarti dependensi rasio wilayah tersebut juga tinggi sehingga satu orang penduduk menanggung banyak orang. Daerah yang memiliki tingkat pengangguran tinggi, biasanya memiliki jumlah penduduk miskin yang banyak.

\section{DAFTAR PUSTAKA}

Agus Widarjono (2007). Ekonometrika : Teori dan Aplikasi Untuk Ekonomi dan Bisnis. Edisi

Kedua, Ekonisia Fakultas Ekonomi Universitas Islam Indonesia, Yogyakarta

Arsyad, L. (2016). Ekonomi Pembangunan. Edisi Kelima. STIE YKPN. Yogyakarta.

Badan Pusat Statistik (2019). Statistik Indonesia 2019. Pusat: Badan Pusat Statistik.

Firmansyah (2016). Produk Domestik Regional Bruto Kabupaten Sambas Menurut Pengeluaran 20112015. Sambas: Badan Pusat Statistik Sambas.

Kanbur, Ravi and Lyn Squire (1999). The Evolution of Thinking about Poverty: Exploring The Interactions.

Kuncoro, Mudrajad (1997). Ekonomi Pembangunan, Teori, masalah dan kebijakan. Cetakan pertama, Unit penerbitan dan percetakan akademi manajemen perusahaan YKPN, Yogyakarta.

Meinny - Kolibu, Vekie Adolf Rumate, Daisy S.M. Engka (2017). Pengaruh Tingkat Inflasi, In ve s ta $s$, Pertumbuhan Ekonomi dan Tingkat Pengangguran Terhadap Tingkat Kemiskinan di Provinsi Sulawesi Utara. Universitas Sam Ratulangi : Jurnal Pembangunan Ekonomi dan Keuangan Daerah, 19 (3), 1-14.

Prasetyoningrum, Ari Kristin dan Sulia Sukmawati (2018). Analisis Pengaruh Indeks Pembangunan Manusia (IPM), Pertumbuhan Ekonomi dan Pengang- 
guran terhadap Kemiskinan di Indonesia. Equilibrium : Jurnal Ekonomi Syariah, 6 (2), 217-237.

Wahyudi, Dicky dan Rejekiningsih, Tri Wahyu (2013). Analisis kemiskinan di Jawa Tengah. Diponegoro Journal of Economics, 2 (1), 1-15

Zuhdiyaty, Noor dan Kaluge, David (2017) Analisis Faktor Faktor yang Mempengaruhi Kemiskinan di Indonesia Selama Lima Tahun Terakhir (Studi Kasus Pada 33 Provinsi). Jurnal Ilmiah Bisnis dan Ekonomi Asia, 11 (2), 27-31 